\title{
Rancang Bangun Aplikasi Pemesanan Pada Cantika Catering Berbasis Web
}

\author{
Sri Muryani' ${ }^{1}$, Devie Safika ${ }^{2}$ \\ ${ }^{1}$ STMIK Nusa Mandiri Jakarta \\ J1. Kramat Raya No. 25 Jakarta Pusat \\ e-mail: sri.smy@nusamandiri.ac.id \\ ${ }^{2}$ Universitas Bisa Sarana Informatika \\ J1. Kamal Raya No. 18, Ringroad barat, Cengkareng, Jakarta Barat \\ e-mail: dekaaa98@gmail.com
}

\begin{abstract}
The system available right now at Cantika Catering is conducted manually, started from recording customer's orders to keep other data related to processes from sales to transactions, keeping the records accurately, and spending less time to search some data. Cantika catering requires information system which can support and deliver satisfactory services for its customers. Therefore, the author tried to compose a research about the sales system in Cantika Catering which was completed by using data collection methods as follows: direct observation, interview, and literature review. Nowadays, Cantika Catering is a business dealing only with food provision service. The design of information system is the best solution to handle problems in this company, and a computerized system will make the company's actvities more effectively and efficiently. Therefore, the researcher has conducted a change of system for Cantika Catering from manual to computerized and web based order transaction.
\end{abstract}

Keywords: Sales Information System, Design Of Information System

\section{PENDAHULUAN}

PT. Mega Cantika Catering adalah bentuk dibidang penyedia makanan berlokasi di Jl. H. Gemin no.102 Kel. Jatikramat Rt/ Rw. 002/002 Pondok Gede Bekasi. Nomor Surat Izin Usaha (SIUP) 510/115 PERINDAG/PB/DC/2005.

Saat ini menyediakan menu box untuk karyawan pabrik, hotel atau perorangan bahkan untuk acara pesta. Kegiatan dalam usaha ini meliputi penjualan jasa membuat makanan yang dibutuhkan pelanggan untuk pesta pernikahan, acara keluarga, ataupun lunch box untuk para karyawan disuatu perusahaan. Untuk melakukan pemesanan hanya dilakukan melalui telepon atau datang langsung ke Cantika Catering dimana hal ini memerlukan banyak waktu. Pada Cantika Catering ini sendiri proses pengolahan data pemesanan masih manual yakni saat melakukan pencatatan transaksi masih dengan tulis tangan. Sehingga data sering tercecer dan tidak rapi. Memberikan informasi seputar menu dan harga kepada konsumen melalui telepon yang memungkinkan masih kurang efektif karena adanya miss communication. Media promosi dengan face to face yang memerlukan banyak waktu, serta jangkauan pemasaran dan penyebaran informasi terhadap konsumen tidak luas . Oleh karena itu peneliti mengajukan melakukan perubahan sistem pada Cantika Catering menjadi terkomputerisasi berbasis website agar tidak terjadi kerumitan saat pencatatan transaksi dimana tidak dilakukannya entry ulang yang memungkinkan terjadinya human error. Terutama dalam efesiensi, promosi dan pemesanan catering yang tidak memerlukan banyak waktu lagi dan dapat di proses dengan cepat.

Menurut (Bowo, 2014, hal. 21) web server merupakan sebuah perangkat lunak atau software dalam server yang berfungsi menerima permintaan berupa halaman web melalui HTTP atau HTTPS dari klien yang dikenal dengan browser web dan mengirimkan kembali (response) hasilnya dalam bentuk halaman-halaman web yang berbentuk dokumen HTML.

Menurut (Krisianto, 2014, hal. 3) web browser adalah software untuk menampilkan halaman website.

\section{METODOLOGI PENELITIAN}

Metode pengumpulan data yang digunakan dalam penelitian ini adalah:

1. Pengamatan Langsung (Observation).

Peneliti melakukan pengamatan langsung di Cantika Catering Bekasi yang berkaitan dengan pemesanan catering. Tujuan dari pengumpulan data ini agar dapat melihat langsung prosedur kerja untuk mengetahui secara pasti segala sesuatu yang diperkukan pada saat terjadinya proses pemesanan catering.

2. Wawancara (Interview). 
Peneliti melakukan wawancara langsung dengan pemilik Cantika Catering yaitu Ibu Megawati Rachman, untuk mendapatkan informasi yang spesifik, jelas dan valid terkait pemesanan pada Cantika Catering.

3. Studi Pustaka (Library Research).

Sistem pendukung untuk mencari berbagai informasi menggunakan studi pustaka denagn mengambil beberapa referensi dari buku maupun penelitian terdahulu.

Metode pengembangan perangkat lunak.

Menurut (Sukamto, 2013, hal. 28) metode waterfall terbagi dalam beberapa tahap.

1. Analisa Kebutuhan Sofware

Dalam tahap ini peneliti menjelaskan tentang analisis kebutuhan dari segi kebutuhan pengunjung, kebutuhan member, dan kebutuhan pada administrator. Pada halaman pengunjung, pengunjung dapat melihat menu makanan yang akan dibeli, pengunjung dapat melihat cara pemesanan makanan, pengunjung dapat melihat profile Cantika Catering, dan pengunjung dapat melakukan registrasi. Pada halaman member, member dapat melakukan login, member dapat melakukan proses pembelian, member dapat melakukan konfirmasi pembayaran, member dapat mengedit data member, member dapat melakukan checkout. Pada halaman administrator, admin dapat melakukan login, admin dapat mengelola data makanan, admin dapat mengelola data pemesanan, admin dapat melihat laporan pemesanan, admin dapat mengedit profile Cantika Catering.

2. Desain

Pada tahap ini peneliti melakukan desain pemakaian struktur data yang tepat didalam proses pembuatan website untuk menjadikan website secara keseluruhan lebih efektif. Peneliti juga menggunakan Struktur Navigasi untuk menggambarkan hubungan dan rantai kerja seluruh elemen-elemen website penjualan makanan yang akan digunakan dalam website. Peneliti juga mengunakan Logical Record Structure (LRS) untuk membuat kita lebih mudah untuk menganalisis pada suatu basis data atau sistem dengan cara yang cepat. Pada User Interface peneliti merancang desain tampilan dengan menentukan warna, konsep web, dan gaya huruf.

3. Code Generation

Peneliti membuat website berbasis object dan pada tahap ini peneliti melakukan pengkodean dengan bahasa pemrograman JavaScript, HTML, PHP, CSS dan MySQL.

4. Testing

Pada tahap proses pengujian, peneliti akan memastikan website yang telah dibuat dengan menggunakan blackbox testing. Hal ini untuk mengetahui bahwa definisi masukan/input yang diberikan akan menghasilkan keluaran/output yang diingkan.

5. Support

Software yang peneliti gunakan dalam pembuatan aplikasi tersebut dengan sistem operasi Dreamweaver $M X$ dan MySQL. Hardware yang digunakan peneliti dengan Processor Intel Core i3 (2.6 Ghz), Hardisk 500GB, dan RAM DDR3 2.0 GB.

\section{HASIL DAN PEMBAHASAN}

PT. Mega Cantika Catering adalah bentuk usaha di bidang jasa tepatnya di di bidang penyedia makanan berlokasi di Jl. H. Gemin no.102 Kel. Jatikramat Rt/ Rw. 002/002 Pondok Gede Bekasi. Nomor Surat Izin Usaha (SIUP) 510/115 PERINDAG/ PB/ DC/ 2005. Dan saat ini menyediakan menu box untuk karyawan pabrik, hotel atau perorangan bahkan untuk acara pesta.

\section{Analisa Kebutuhan \\ Analisa Kebutuhan Pengguna}

Pada aplikasi e-commerce terdapat front-end, database dan back-end yang saling berinteraksi dalam lingkungan sistem. Pengguna website ada 2, yaitu admin, dan pengunjung. Setiap pengguna mempunyai kebutuhan informasi yang berbeda yaitu:

1. Admin

1.1. Admin dapat mengedit profil, password, dan email admin.

1.2. Admin dapat menambah, mengedit dan menghapus kategori, jenis menu, menu, data bank dan biaya kirim.

1.3. Admin dapat menambah, mengedit dan menghapus informasi tentang website.

1.4. Admin dapat mengubah status konfirmasi pembayaran.

1.5. Admin dapat mengubah atau memperbaharui password.

1.6. Admin dapat melihat detail data order dan laporan penjualan perhari, perbulan sampai pertahun.

2.

2.1. Pengunjung $\quad$ Pengunjung dapat melihat menu dan detail menu di konten beranda dan kategori menu.

2.2. Pengunjung dapat membaca konten cara pembelian dan tentang kami.

2.3. Pengunjung dapat melihat profil Cantika Catering.

2.4. Pengunjung dapat melakukan registrasi.

3. Member

3.1. Member dapat melakukan $\operatorname{login}$ 

3.2. Member dapat melakukan proses pembelian
3.3. Member dapat melakukan konfirmasi pembayaran
3.4. Member dapat mengedit data member.
3.5. Member dapat melakukan checkout.

\section{Analisa Kebutuhan Sistem}

1. Sistem Administrator

Administrator harus login. Setelah admin berhasil login, selanjutnya admin akan masuk ke halaman beranda administrator dan kontenkonten yang tersedia untuk mengatur data-data dan informasi yang muncul di website, dan dapat melihat order pembelian masuk dan detail transaksi yang dihasilkan.

2. Sistem Kategori Menu dan Keranjang Belanja. Menu yang dipilih akan masuk kedalam keranjang belanja, didalam keranjang belanja menu masih dapat diubah jumlah beli, atau menambah menu lagi dan jika sudah sesuai keinginan dapat melanjutkan pembelian

\section{Use Case Diagram}

Berikut adalah model use case diagram aplikasi pemesanan pada Cantika Catering.

1. Use Case

Login

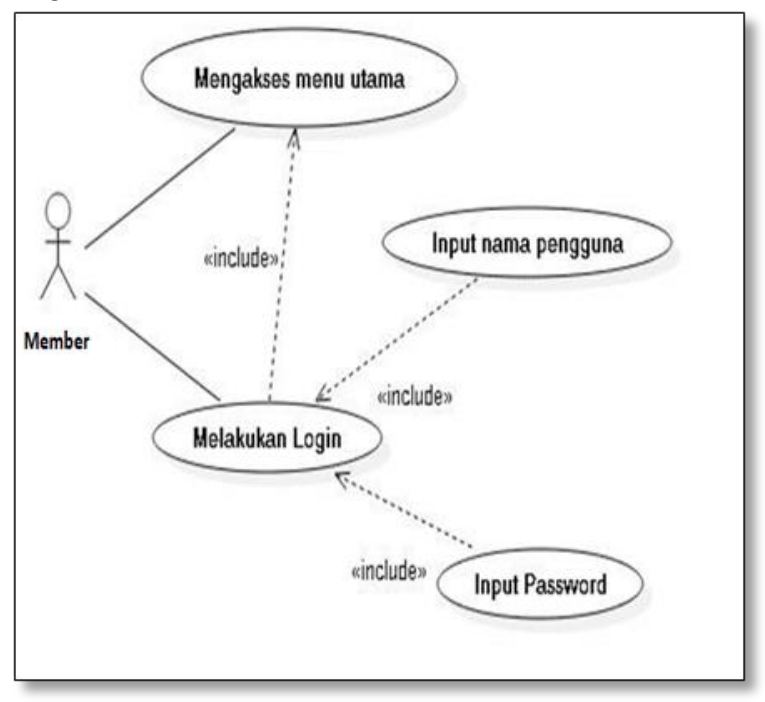

Sumber: Hasil Penelitian 2018

Gambar 1. Use Case Diagram Login

Tabel 1. Deskripsi Use case Diagram Login

\begin{tabular}{llr}
\hline \multicolumn{3}{c}{ Use Case Narative Login } \\
\hline Tujuan & Melakukan login dan \\
& masuk ke dalam sistem \\
& web pemesanan & \\
\hline Deskripsi & Sistem & ini \\
& memungkinkan & aktor \\
\hline
\end{tabular}

\begin{tabular}{|c|c|}
\hline & $\begin{array}{l}\text { untuk mengakses } \\
\text { sistem web pemesanan }\end{array}$ \\
\hline \multicolumn{2}{|c|}{ Skenario Utama } \\
\hline Aktor & Member \\
\hline Kondisi Awal & $\begin{array}{l}\text { Aktor membuka web } \\
\text { pemesanan }\end{array}$ \\
\hline Aksi Aktor & Reaksi Sistem \\
\hline $\begin{array}{l}\text { 1. Aktor } \\
\text { memilih } \\
\text { tombol } \\
\text { masuk } \\
\text { 2. Aktor } \\
\text { memilih } \\
\text { tombo batal }\end{array}$ & $\begin{array}{ll}\text { 1. } & \text { Sistem akan } \\
\text { menampilkan textbox } \\
\text { untuk mengisi nama } \\
\text { pengguna dan } \\
\text { password. } \\
\text { 2. Sistem akan } \\
\text { membatalkan proses } \\
\text { dan keluar dari form } \\
\text { login. }\end{array}$ \\
\hline Kondisi Akhir & $\begin{array}{l}\text { Jika perintah sesuai } \\
\text { maka sistem akan masuk } \\
\text { kedalam web pemesanan } \\
\text { dan melakukan aktifitas } \\
\text { disalam sistem. }\end{array}$ \\
\hline
\end{tabular}

Sumber: Hasil Penelitian (2018).

2. Use Case Menu Utama/ Beranda.

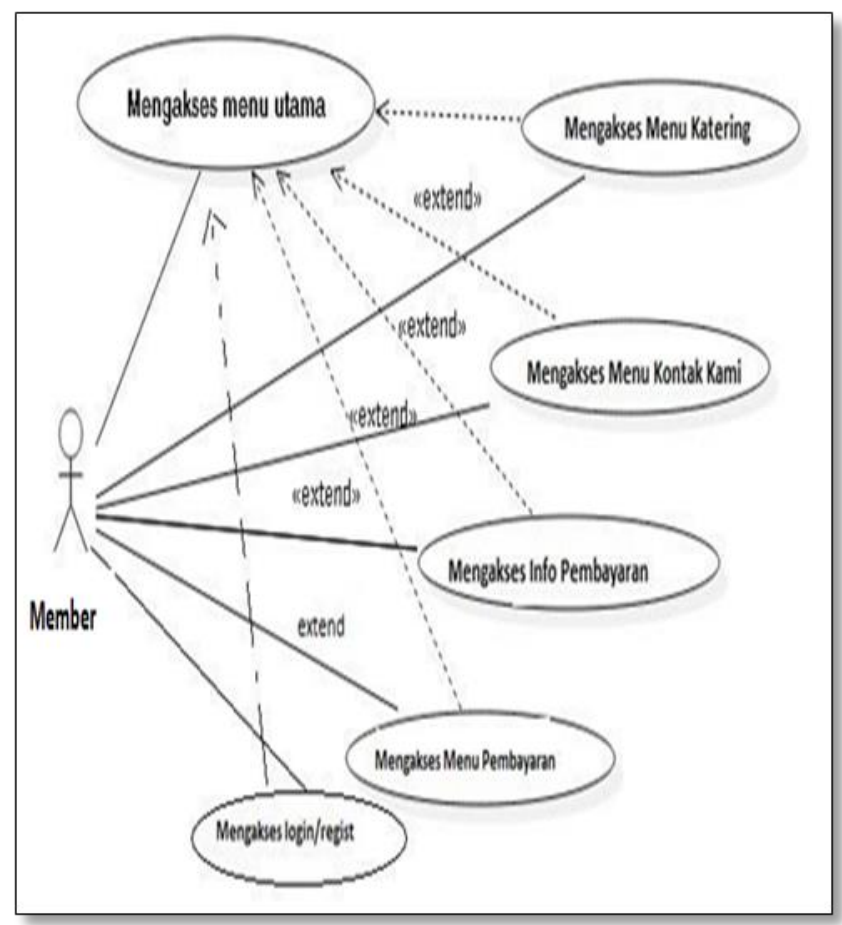

Sumber: Hasil Penelitian 2018

Gambar 2. Use Case Diagram Menu Utama

Tabel 2. Deskripsi Use case Diagram Menu Utama

\begin{tabular}{llr}
\hline \multicolumn{3}{c}{ Use Case Narative Menu Utama } \\
\hline Tujuan & Member & dapat \\
& mengakses menu yang \\
& ada pada menu utama \\
\hline
\end{tabular}




\begin{tabular}{|c|c|}
\hline & $\begin{array}{l}\text { yaitu menu catering, } \\
\text { menu kontak kami, menu } \\
\text { info pembayaran dan } \\
\text { menu login/register. }\end{array}$ \\
\hline Deskripsi & $\begin{array}{lr}\text { Sistem } & \text { ini } \\
\text { memungkinkan } & \text { aktor } \\
\text { untuk mengelola seluruh } \\
\text { menu yang ada dalam } \\
\text { menu utama. }\end{array}$ \\
\hline \multicolumn{2}{|c|}{ Skenario Utama } \\
\hline Aktor & Member \\
\hline Kondisi Awal & $\begin{array}{l}\text { Aktor membuka web } \\
\text { pemesanan dan masuk ke } \\
\text { dalam menu catering }\end{array}$ \\
\hline Aksi Aktor & Reaksi Sistem \\
\hline 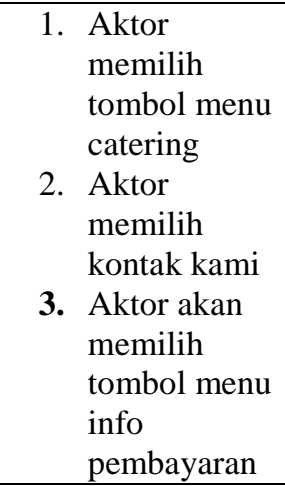 & 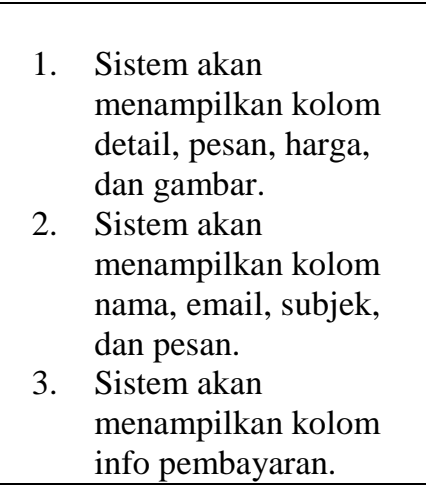 \\
\hline Kondisi Akhir & $\begin{array}{l}\text { Jika perintah sesua maka } \\
\text { sistem akan measuk } \\
\text { kedalam menu utama dan } \\
\text { melakukan aktifitas } \\
\text { didalam sistem menu } \\
\text { utama atau menu beranda. }\end{array}$ \\
\hline
\end{tabular}

Sumber: Hasil Penelitian (2018).

\section{Rancangan Antar Muka}

Berikut ini adalah rancangan antar muka yang digunakan untuk desain aplikasi pemesanan pada Cantika catering.

a. Rancangan Halaman Login

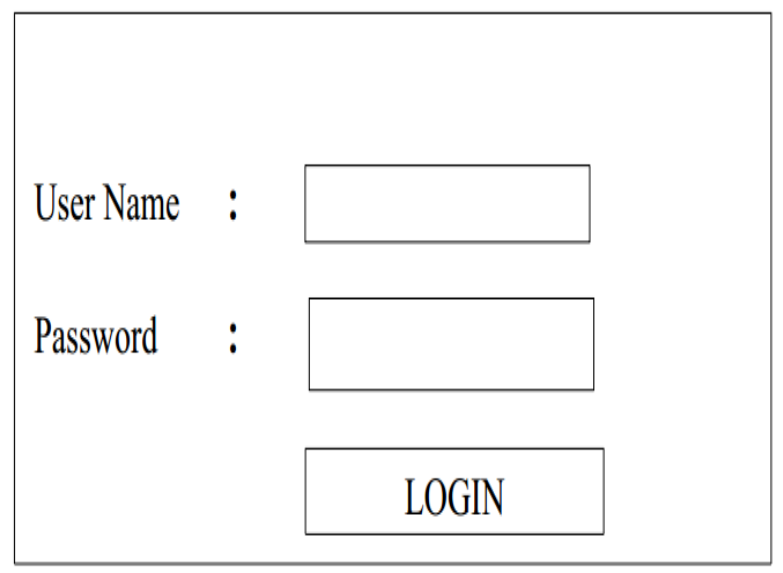

Sumber: Hasil Penelitian (2018)

Gambar 3. Rancangan Halaman Login b. Rancangan Halaman Menu

\begin{tabular}{|c|c|c|}
\hline \multicolumn{3}{|c|}{ Header } \\
\hline \multicolumn{3}{|c|}{ Logo } \\
\hline & \multicolumn{2}{|c|}{ List Paket Menu } \\
\hline \multirow[t]{2}{*}{ Paket Menu } & & \\
\hline & List & List \\
\hline \multirow{2}{*}{ Kontak Kami } & & \\
\hline & List & List \\
\hline Pembayaran & Menu & Menu \\
\hline
\end{tabular}

Sumber: Hasil Penelitian (2018)

Gambar 4. Rancangan Halaman Menu

c. Rancangan Halaman Pemesanan

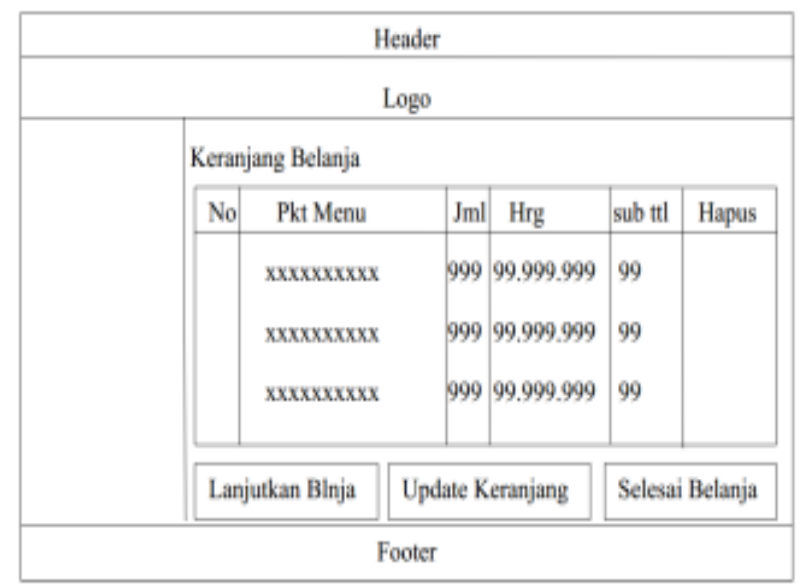

Sumber: Hasil Penelitian (2018)

Gambar 5. Rancangan Halaman Pesanan

\section{Struktur Navigasi}

Dalam pembuatan web pemesanan pada Cantika catering dibutuhkan desain struktur navigasi sebagai berikut: 


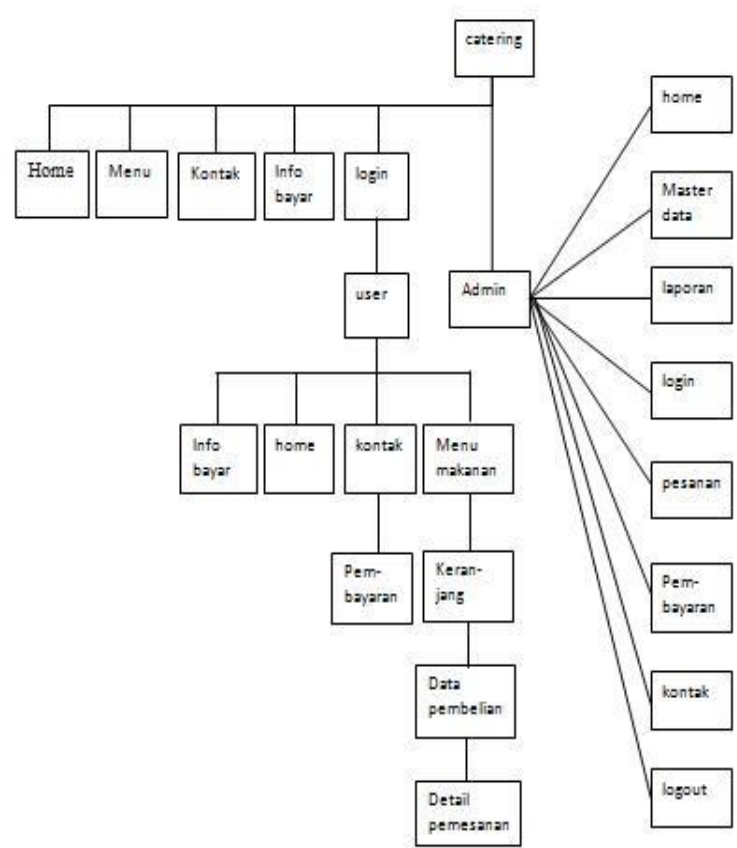

Sumber: Hasil Penelitian (2018)

Gambar 5. Struktur Navigasi

\section{Logical Record Structure}

Menurut (Indrajani, 2014, hal. 2) basis data adalah merupakan suatu kumpulan data yang berhubungan secara logis dengan deskripsi data tersebut, yang dirancang untuk memenuhi informasi yang dibutuhkan oleh suatu organisasi.

Menurut (Andriansyah, 2016, hal. 53) menyimpulkan bahwa LRS merupakan transformasi dari penggambaran ERD dalam bentuk yang lebih jelas dan mudah untuk dipahami.

Berikut ini adalah rancangan database pemesanan pada Cantika catering.

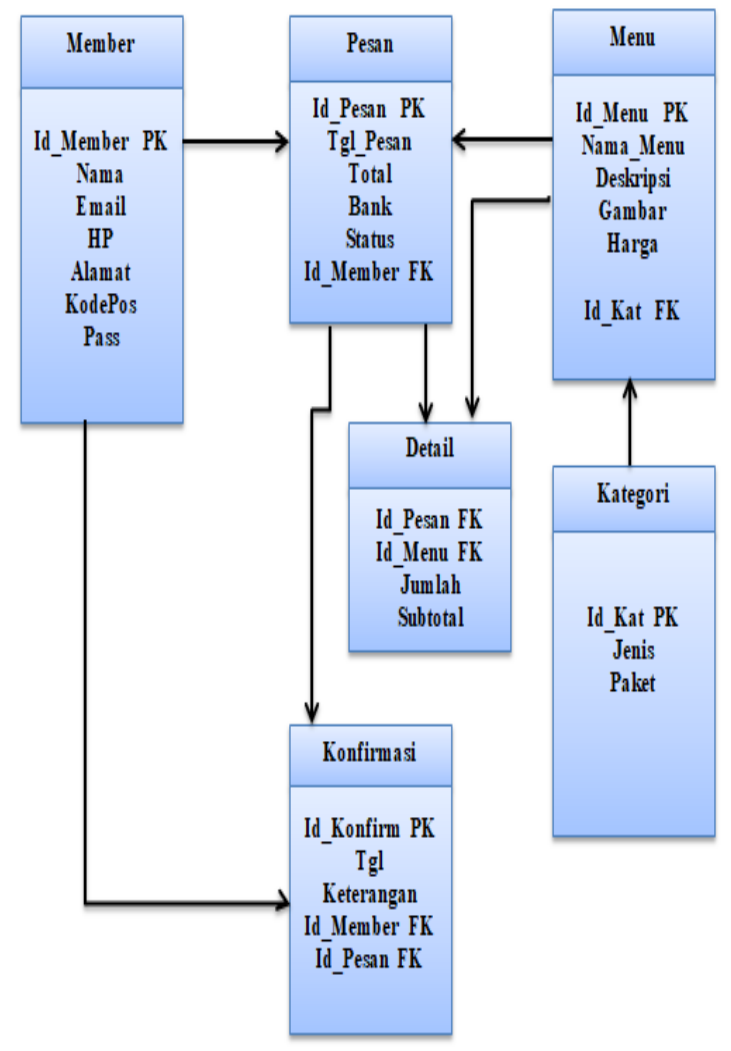

Sumber: Hasil Penelitian (2018)

Gambar 6. LRS Pemesanan Cantika Catering

Dalam rancangan database menggunakan LRS, bisa dilihat tabel yang ada yaitu kategori, menu, member, pesan, detail dan konfirmasi. Tabel kategori berisi kategori menu, misalnya makanan, minuman, camilan, buah, makanan penutup. Menu berisi berbagai jenis menu makanan dan minuman yang disediakan oleh Cantika Catering. Member berisi data pelanggan yang sudah mendaftarkan diri, atau sudah register. Tabel pesan berisi berbagai pesanan menu catering. Tabel konfirmasi berfungsi bagi pelanggan yang akan melakukan konfirmasi pembayaran.

\section{Interface}

a. Registrasi Member 


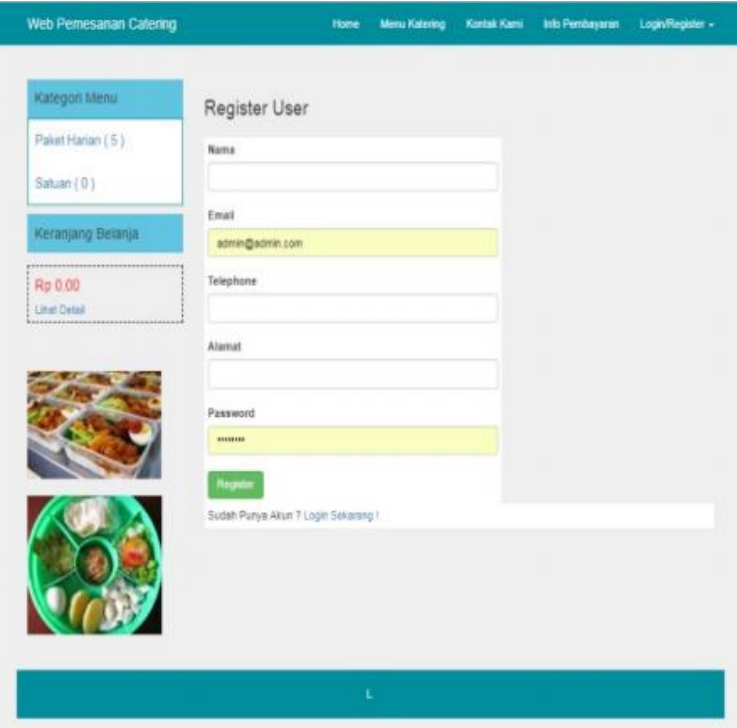

Sumber: Hasil Penelitian (2018)

Gambar 7. Halaman Regsitrasi Member

Halaman registrasi berungsi untuk pengunjung yang ingin mendaftarkan diri menjadi member. Untuk melakukan pesanan, memang pengunjung diharuskan untuk registrasi.

\section{b. Login}

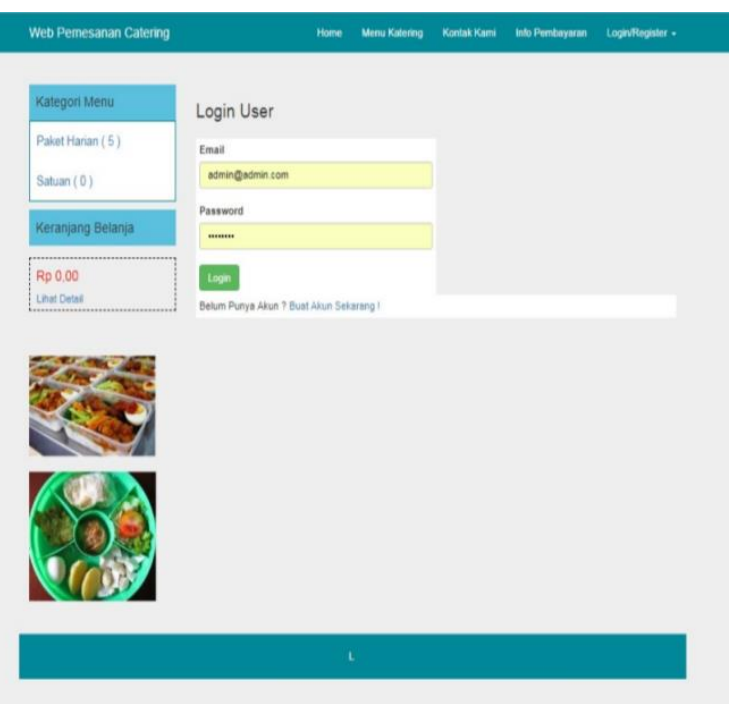

Sumber: Hasil Penelitian (2018)

Gambar 8. Halaman Login

Untuk pengunjung yang sudah registrasi dan sudah menjadi member, bisa melakukan login terlebih dahulu. Pada halaman login, member bisa memasukkan email dan password, lalu klik login. Jika email dan password benar, maka akan masuk ke menu beranda.

\section{c. Beranda}

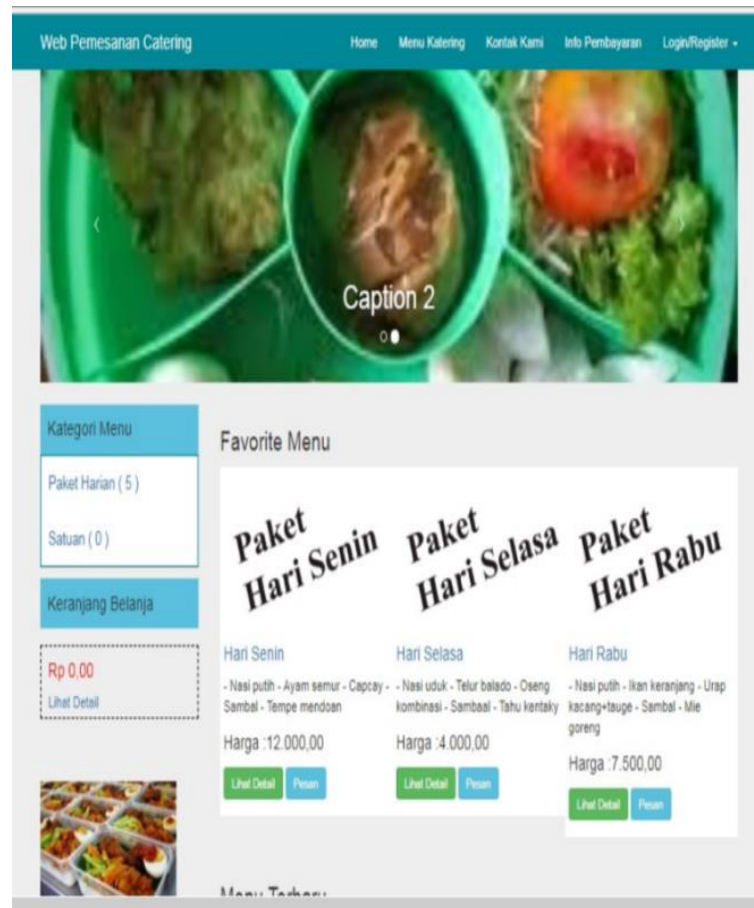

Sumber: Hasil Penelitian (2018)

Gambar 9. Halaman Beranda

Pada halaman beranda di tampilkan berbagai menu dan paket catering yang bisa di pilih oleh member. Ada menu paket harian yaitu paket hari senin, selasa, rabu, kamis, jum'at yang menawarkan beraneka ragam menu. Ada paket pesta seperti pernikahan, arisan, family gathering, maupun paket ulang tahun. Menu yang disediakan mulai makanan pembuka, makanan utama, aneka minuman, camilan dan makanan penutup.

Pada tab menu di atas ada pilihan menu home, kontak kami, menu info pembayaran, login/registrasi jika ingin melakukan pemesanan catering.

\section{d. Keranjang Pesanan}

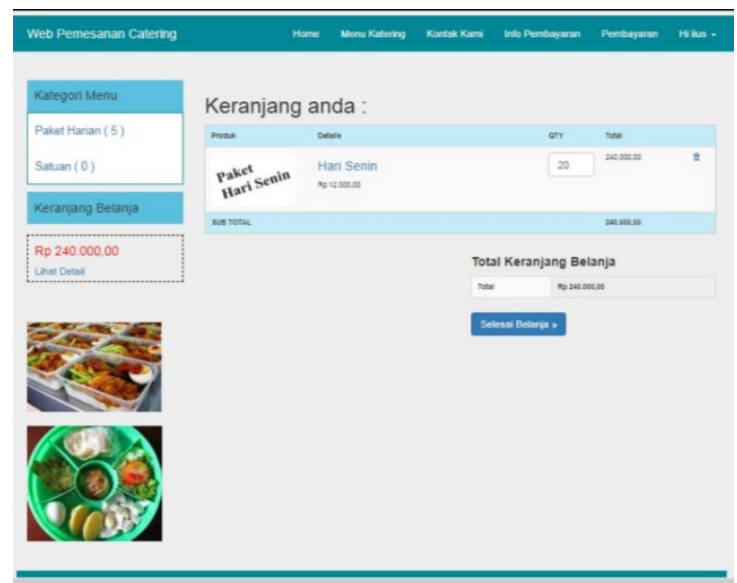

Sumber: Hasil Penelitian (2018)

Gambar 10. Keranjang Pesanan 
Pada halaman keranjang pesanan berisi menumenu yang sudah dipilih, jumlahnya berapa, dan berapa total yang sudah dipesan oleh member.

e. Informasi Pembayaran

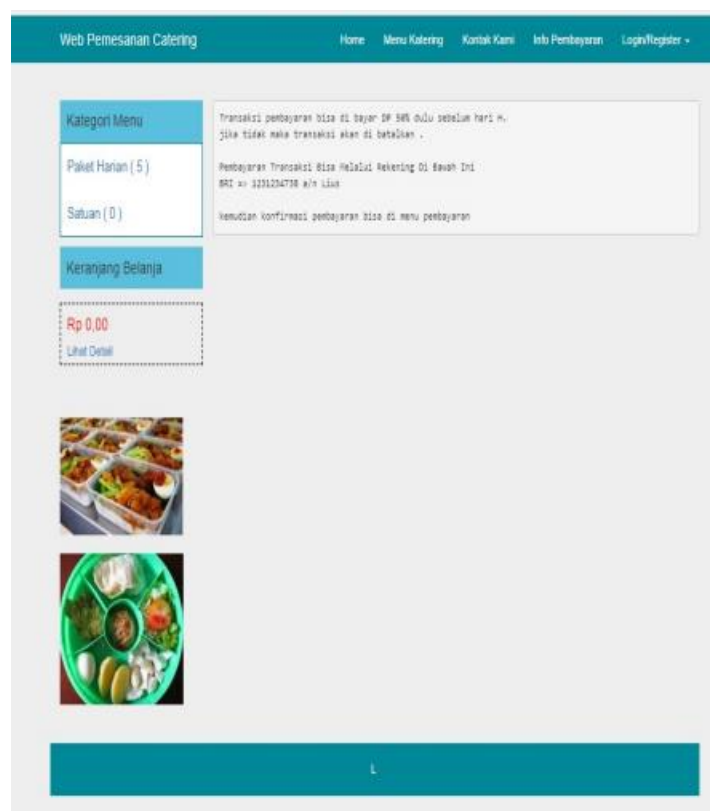

Sumber: Hasil Penelitian (2018)

Gambar 11. Informasi Pembayaran

Pada menu informasi pembayaran menampilkan informasi tentang pembayaran yang harus dilakukan oleh member dan tata cara pembayaran.

\section{f. Pembayaran dan Konfirmasi Bayar}

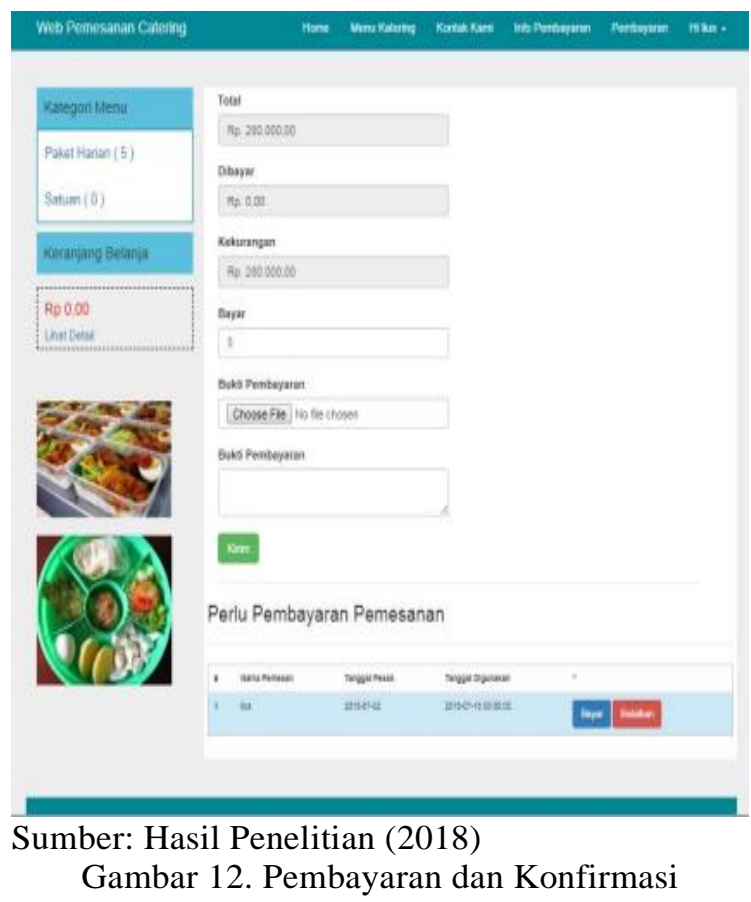

Pada halaman pembayaran dan konfirmasi berisi tentang konfirmasi pembayaran yang sudah dilakukan.

\section{KESIMPULAN}

Berdasarkan uraian pembahasan yang sudah peneliti sampaikan, maka berikut kesimpulan yang dapat peneliti rangkum dari penelitian pada Cantika Catering:

1. Proses pemesanan pada Cantika Catering masih menggunakan pencatatan manual, sehingga arsip tidak rapi dan proses pembuatan laporan lebih lama.

2. Aplikasi pemesanan catering berbasis web merupakan solusi terbaik untuk mengatasi permasalahan pada Cantika Catering.

3. Aplikasi pemesana pada Cantika Catering berbasis web bisa menjangkau pangsa pasar yang lebih luas.

4. Kegiatan proses bisnis lebih efektif dan efisien.

5. Penyimpanan data lebih rapi dalam bentuk database.

\section{REFERENSI}

Abdullah, R. (2015). Web programming is Easy. Jakarta: Elex Media Komputindo.

Ahmadi. (2013). Kolaborasi SQL dan ERD dalam Implementasi Database. Yogyakarta: Andi.

Andriansyah, D. (2016). Sistem Informasi Pendaftaran Event Dengan PHP Untuk Panduan Skripsi. Jakarta: CV. Asfa Solution.

Bowo, E. (2014). Panduan Untuk Web Master. Jakarta: Jasakom.

E, N. H. (2016). Pengantar Informasi Teknologi. Jakarta: Baduose Media.

Fatansyah. (2015). Basis Data. Bandung: Informatika.

Ichsan. (2013, November). Sistem Pendukung Keputusan Pemilihan Penerima Beasiswa Mahasiswa Kurang Mampu Pada STMIK BUDIDARMA Medan Menerapkan Metode Profile Matching. Kursor, 5(1), 2. Dipetik April 14, 2016, dari http://pelitainformatika.com/berkas/jurnal/1.\%20TM\% 20Syahru.pdf

Indrajani. (2014). Pengantar Sistem Basis Data (Case Study All In One). Jakarta: PT. Elex Media Komputindo.

Krisianto, A. (2014). Internet Untuk Pemula. Jakarta: PT. Elex Media Komputindo.

M, P. S. (2013). Tujuh Langkah Praktis Pembangunan Basis Data. Jakarta: PT. Elex Media Komputindo. 
Sidik, B. H. (2013). Pemrograman Web dengan HTML. Bandung: Informatika.

Sukamto, S. (2013). Rekayasa Perangkat Lunak. Bandung: Informatika.

Winarno, E. (2014). Pemrograman Web Berbasis HTML5, PHP, dan Javascript. Semarang: Smitdev Comunity.

\section{PROFIL PENULIS}

Sri Muryani, Tahun 2011 Lulus dari Program Strata Dua (S2) ilmu Komputer pada Pasca Sarjana STMIK Nusa Mandiri Jakarta. Saat ini bekerja sebagai tenaga pengajar pada STMIK Nusa Mandiri Jakarta dengan jabatan Fungsional Akademik Asisten Ahli diperoleh tahun 2013.

Devie Safika, Tahun 2018 Lulus dari Program Diploma Tiga program studi Sistem Informasi Akuntansi Universitas Bina Sarana Informatika 